\title{
Cytochrome oxidase subunit I (COI) DNA sequence divergence between two cryptic species of Oryzias in South Korea
}

\author{
Dong-Su In ${ }^{1}$, Eun-Sook Choi ${ }^{2}$, Ju-Duk Yoon ${ }^{1}$, Jeong-Hui Kim², Jun-Il Min ${ }^{3}$, Seung-Ho Baek ${ }^{2}$, Min-Ho Jang, \\ ${ }^{1}$ Biological Resource Center, Kongju National University, Gongju, 314-701, Korea \\ ${ }^{2}$ Department of Biology Education, Kongju National University, Gongju, 314-701, Korea \\ ${ }^{3}$ Department of Animation, Kongju National University, Gongju, 314-701, Korea
}

\begin{abstract}
Oryzias latipes and Oryzias sinensis are indigenous species found in Japan, China, and other East Asian countries, including Korea. Based on morphological differences, the species have been classified distinctly. However, the range of morphological characters such as the number of gill rakers, vertebrae, and spots on the lateral body overlaps and is too vague for clear identification, so their classification based on their morphological characteristics remains uncertain. In this study, the mitochondrial cytochrome oxidase subunit I (COI) gene, which is used for DNA barcoding, was applied to clarify interspecific variation of $O$. latipes and $O$. sinensis. Intraspecific genetic diversity was calculated to identify correlations with geographic distributions. We studied two species collected from 55 locations in Korea. All individuals carried a 679-base pair gene without deletion or insertion. Between species, 525 base pairs of the gene were shared. The Kimura two parameter (K2P) distance of O. latipes and O. sinensis was $0.41 \%$ and $1.39 \%$, respectively. Mean divergence within genera was $23.5 \%$. Therefore, the species were clearly different. The distance between O. latipes and O. sinensis was $14.0 \%$, which is the closest within genera. Interestingly $O$. latipes from the Japanese and Korean group represented $16.5 \%$ distant. These results were derived from geohistorical and anthropogenic environmental factors. The O. latipes haplotypes were joined in only one group, but O. sinensis was divided into two groups, one is found in the Han River and upper Geum River watershed; the other is found in the remaining South Korean watersheds. Further studies will address the causes for geographic speciation of $O$. sinensis haplotypes.
\end{abstract}

Key words: cytochrome oxidase subunit I, geographic distribution, K2P distance, Oryzias latipes, Oryzias sinensis

\section{INTRODUCTION}

Morphological identification, the most common method for classification, has been employed for many years. Studies involve measuring and comparing the phenotypes of target species, sometimes by microscopic examination. This method is normal and sound when it applies to well-known taxa; however, it is not always efficient for species identification, unless the phenotype is obvious. To overcome this problem, a taxonomic system based on
DNA analysis was established in the early 2000s (Tautz et al. 2002, 2003).

Mitochondrial DNA cytochrome oxidase subunit I (mtDNA COI) has been proposed for used in animal bioidentification because the COI gene could differentiate nearly all animal species with only a single gene sequence (Hebert et al. 2003, 2005). In the early 2000s, various taxonomic studies were carried out using the COI gene

\section{Open Access http://dx.doi.org/10.5141/ecoenv.2013.159}

This is an Open Access article distributed under the terms of the Creative Commons Attribution Non-Commercial License (http://creativecommons. org/licenses/by-nc/3.0/) which permits unrestricted non-commercial use, distribution, and reproduction in any medium, provided the original work is properly cited.
Received 11 March 2013, Accepted 12 July 2013

*Corresponding Author

E-mail: jangmino@kongju.ac.kr

Tel: +82-41-850-8285 


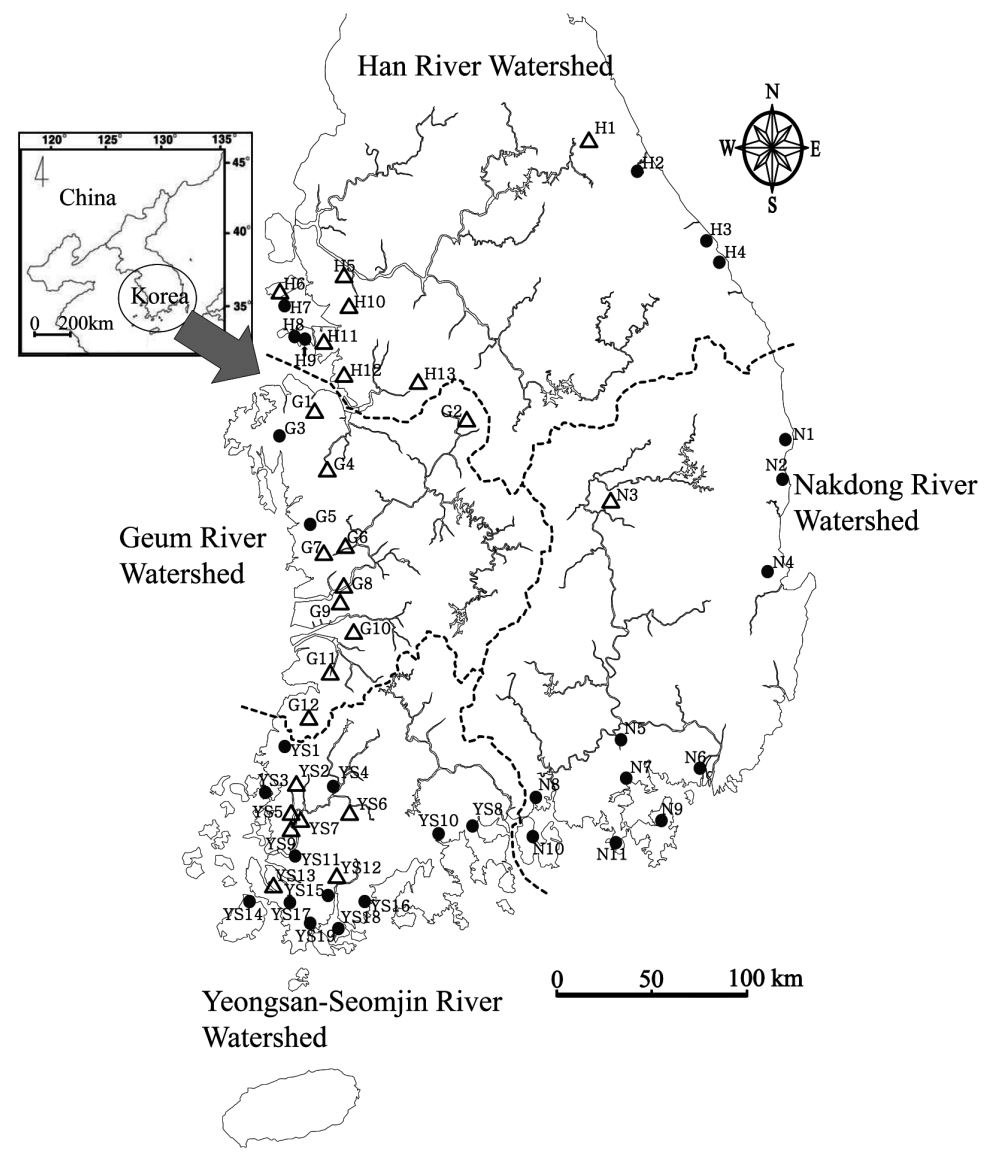

Fig. 1. Oryzias collection sites in South Korea.

(Hebert et al. 2003, 2004a, 2004b, 2005, Smith et al. 2006, 2007, Bucklin et al. 2010). The universal primer for the COI gene is very stable and attaches at the $5^{\prime}$ end of the animal gene (Folmer et al. 1994, Zhang and Hewitt 1997). The COI provides profound insights into phylogenetic studies more than other mitochondrial genes such as cytochrome b (Simmons and Weller 2001), because changes in the amino acid sequence occur more slowly (Lynch and Jarrell 1993). Moreover, mtDNA extraction and sequencing are easy because the small multi-copy mitochondrial genome is located in each cell. Inter-specific variation is high and intra-specific variation is low, making species classification clears (Jin 2012).

Oryzias latipes and Oryzias sinensis (genus Oryzias) are indigenous species distributed in South Korea, China, Japan, and East Asia. Both species are shoaling fish that stay near the water surface and favor static, shallow waters such as reservoirs, swamps, and small streams (Kim and Park 2002). They were classified by morphological analysis as different species in the early 1990s; the Chi- na-western Korea group is designated $O$. sinensis and the eastern Korea group is O. latipes (Kim and Lee 1992, Kim and Kim 1993). However, the range of classification keys, number of gill rakers, vertebrae, and spots on the lateral body overlap and are too vague for clear identification, so debate regarding their classification continues.

In this study, the mitochondrial COI region used for DNA barcoding was applied to clarify the interspecific variation of O. latipes and O. sinensis. Intraspecific genetic diversity was also calculated to identify the correlation between geographic distributions.

\section{MATERIALS AND MEHTODS}

\section{Sample collection and identification of genus Oryzias}

Sampling was conducted from 2009 to 2011 and sites were selected based on literature and government reports 
(Appendix 1). Other sites were chosen based on the possibility of Oryzias habitation, even in the absence of records of their presence. Samples were collected at 55 sites, most of which were located in the mid-lower parts of streams (Fig. 1, Appendix 1). At each site, three specimens were chosen for preservation in $99.9 \%$ ethanol; other specimens were released at the site of capture. After sample moved to the laboratory, each specimen was identified, labeled for individual identification, and measured total length $(\mathrm{mm})$, standard length $(\mathrm{mm})$ and body weight (g). Spots on the lateral body were used for identification (Park et al. 2006); if spots were distributed on the caudal peduncle, the specimen was classified as O. latipes and if not, it was classified as $O$. sinensis.

\section{DNA analysis}

We analyzed 165 specimens from 55 sites. DNA extracts were prepared from muscle tissue (about $30 \mathrm{mg}$ ) using SolGent ${ }^{\mathrm{TM}}$ Genomic DNA Prep Kit (Solgent, Daejoen, South Korea). To amplify the COI gene from mitochondrial DNA, PCR was performed with primers FishF2 (5'-TCAACYAATCAYAAAGATAT-3') and FishR2 (5'-ACTTCYGGGTGRCCRAARAA-3') (Ward et al., 2005). The $50 \mu \mathrm{l}$ PCR mixture included $5 \mu \mathrm{l} 10 \times$ reaction buffer, $1 \mu \mathrm{l}$ each primer ( $10 \mathrm{pmole} / \mu \mathrm{l}), 4 \mu \mathrm{dNTP}(2.2 \mathrm{mM}$ each), $0.25 \mu \mathrm{l}$ TaKaRa Ex Taq ${ }^{\mathrm{TM}}$ (Takara, Shiga, Japan) and $4 \mu \mathrm{l}$ template DNA ( $50 \mathrm{ng} / \mu \mathrm{l})$. Amplifications were performed using a C1000 gradient thermal cycler (Bio-RAD, Foster City, CA, USA). Cycling included an initial step of $3 \mathrm{~min}$ at $95^{\circ} \mathrm{C}$ followed by 40 cycles of $0.5 \mathrm{~min}$ at $95^{\circ} \mathrm{C}, 0.5 \mathrm{~min}$ at $55^{\circ} \mathrm{C}$, and $1 \mathrm{~min}$ at $72^{\circ} \mathrm{C}$, followed by elongation for 7 min at $72^{\circ} \mathrm{C}$. PCR products were analyzed by $1 \%$ agarose gel electrophoresis, and then purified with a Solg ${ }^{\mathrm{TM}}$ PCR Purification Kit (SolGent, Daejoen, South Korea). Bidirectional sequencing was performed with the FishF2 and FishR2 primers and an 3730xl DNA Analyzer (Applied Biosystems $^{\circledast}$, Foster City, CA, USA) with the BigDye ${ }^{\circledast}$ Terminator v3.1 Cycle Sequencing Kit (Applied Biosystems ${ }^{\circledR}$ ). Contigs of DNA sequences were generated in CodonCode aligner ver. 3.7.1 (CodonCode Corporation, Dedham, MA, USA). Sequences were aligned with BioEdit ver. 7.0.0 by using the ClustalW Multiple alignment method. Aligned sequences of genus Oryzias and references (6 other Oryzias species and Hyporhamphus sajori as the outgroup) from GenBank (gi208341979; gi253960407; gi314909980; gi253960477; gi253960463; gi253960435; gi253960393; gi254939398; gi253960421) were compared using MEGA5 (Tamura et al. 2011). Neighbor-joining (NJ) was used for phylogenetic analysis. To assess statistical reliability, an
NJ tree was generated by bootstrapping with 1000 replications (Felsenstein 1993) and Kimura two parameter (K2P) distances were determined to provide a graphic representation of the patterning of divergence between species. Sequence divergences were calculated using the K2P distance model (Kimura 1980). All Oryzias sequences include references calculated with NETWORK ver. 4.6.11 using the median-joining network option for intraspecific relationship (Bandelt et al. 1999) to identify relationships.

\section{RESULTS}

\section{Analysis of the mtDNA COI gene}

The COI sequence length was 679-bp and there were no insertions or deletions in any specimen. The COI gene in O. latipes included 629 conserved bp and 23 variable bp. Base compositions were: A, 22.8\%; T, 19.5\%; G, 30.9\%; C, $26.8 \%$. In O. sinensis, the COI gene included 620 conserved and 32 variable bp. Base composition was slightly different in O. latipes: A, 23.7\%; T, 17.9\%; G, 31.9\%; C, $26.5 \%$. The sequence variation in $O$. sinensis was relatively greater than in $O$. latipes. The overlapping sequence in both species was 525-bp long.

The K2P distance of O. latipes was $0.41 \%$, and the distance for $O$. sinensis was 3 times larger, at $1.39 \%$. Mean divergence within genera was $23.5 \%$. Therefore, the species were obviously different. The distance of $O$. latipes and $O$. sinensis was $14.0 \%$, which is the closest within genera. Conversely, O. latipes and O. marmoratus showed 26.5\% distance, so the farthest within genera. Moreover, interestingly $O$. latipes from Japanese group and Korean group represented $16.5 \%$ of distance (Table 1 ).

\section{Molecular phylogeny of genus Oryzias}

The molecular phylogeny results indicate O. latipes and $O$. sinensis in South Korea were clearly branched under 100 bootstrapping (BP) value. O. latipes formed a single group including the GenBank reference gi208341979. The O. sinensis group with GenBank reference gi314909980 was divided into two groups. The $\mathrm{BP}$ value of the $O$. sinensis groups was 99. O. latipes in Japan comprise a different branch with a BP value $<89$ (Fig. 2). A total of 19 O. latipes haplotypes from 30 sites were identified. The estimated number of mutations in the shortest tree within torso was 3 , and the estimated number of mutations in the shortest tree was 25. There was only one network of $O$. latipes in South Korea. In contrast, 14 O. sinensis haplotypes were 


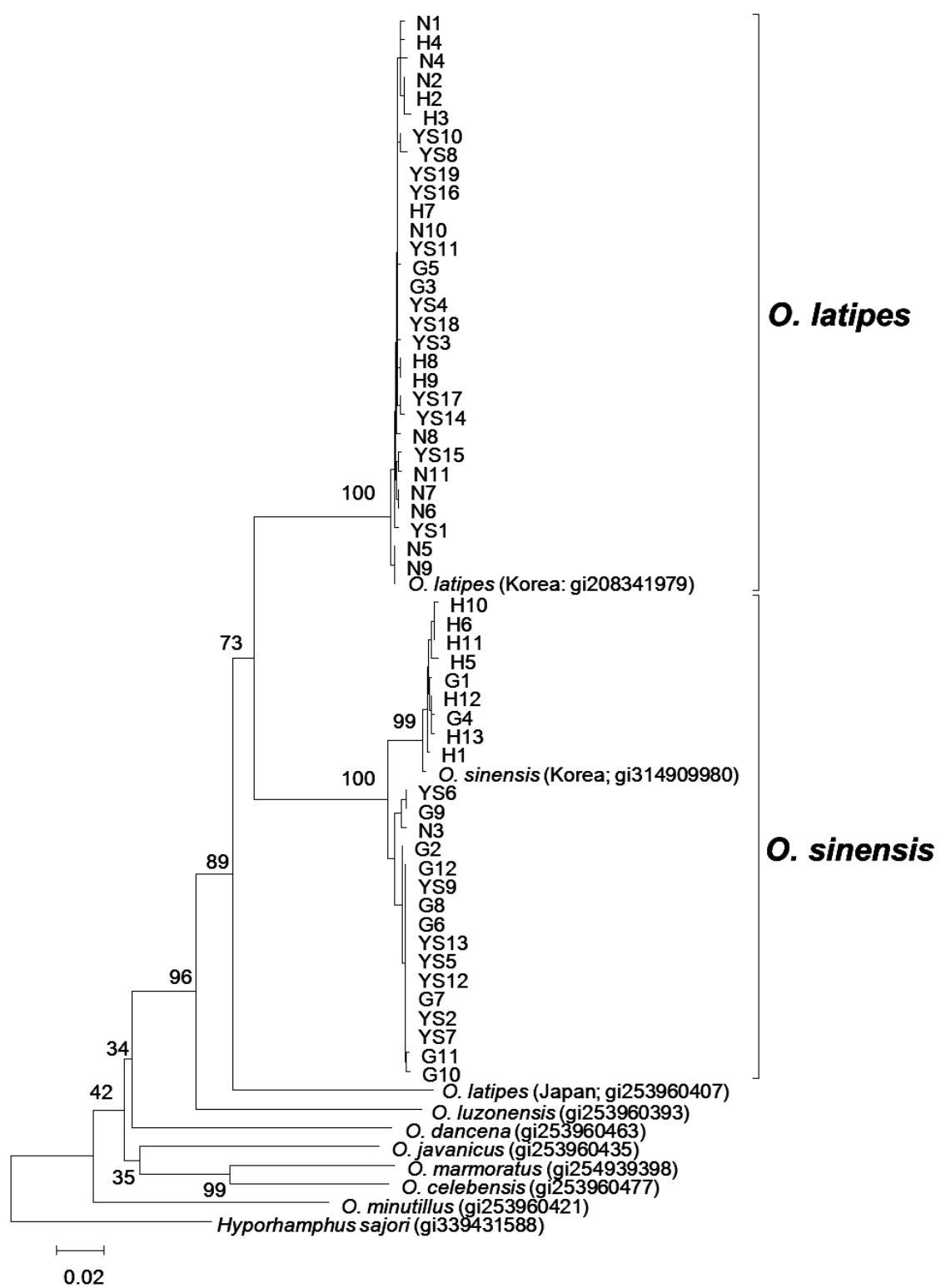

Fig. 2. Molecular phylogeny of Oryzias species using the Neighbor-joining method in MEGA5.

Table 1. Matrix of K2P (Kimura 2 Parameter) for 9 Oryzias species. Hyporhamphus sajori is an outgroup

\begin{tabular}{lcccccccccc}
\hline \multicolumn{1}{c}{ Species } & 1 & 2 & 3 & 4 & 5 & 6 & 7 & 8 & 9 \\
\hline 1 O. latipes (Korea) & 0.000 & & & & & & & & \\
2 O. latipes (Japan) & 0.165 & 0.000 & & & & & & & \\
3 O. sinensis (Korea) & 0.140 & 0.180 & 0.000 & & & & & & \\
4 O. celebensis & 0.248 & 0.260 & 0.242 & 0.000 & & & & & \\
5 O. dancena & 0.232 & 0.253 & 0.246 & 0.235 & 0.000 & & & & \\
6 O. javanicus & 0.243 & 0.245 & 0.239 & 0.212 & 0.242 & 0.000 & & & \\
7 O. luzonensis & 0.194 & 0.215 & 0.195 & 0.264 & 0.255 & 0.217 & 0.000 & & \\
8 O. marmoratus & 0.243 & 0.264 & 0.250 & 0.145 & 0.256 & 0.230 & 0.265 & 0.000 & \\
9 O. minutilus & 0.253 & 0.235 & 0.237 & 0.217 & 0.222 & 0.253 & 0.264 & 0.251 & 0.000 \\
10 Hyporhamphus sajori & 0.273 & 0.252 & 0.248 & 0.265 & 0.264 & 0.225 & 0.249 & 0.274 & 0.227 & 0.000 \\
\hline
\end{tabular}




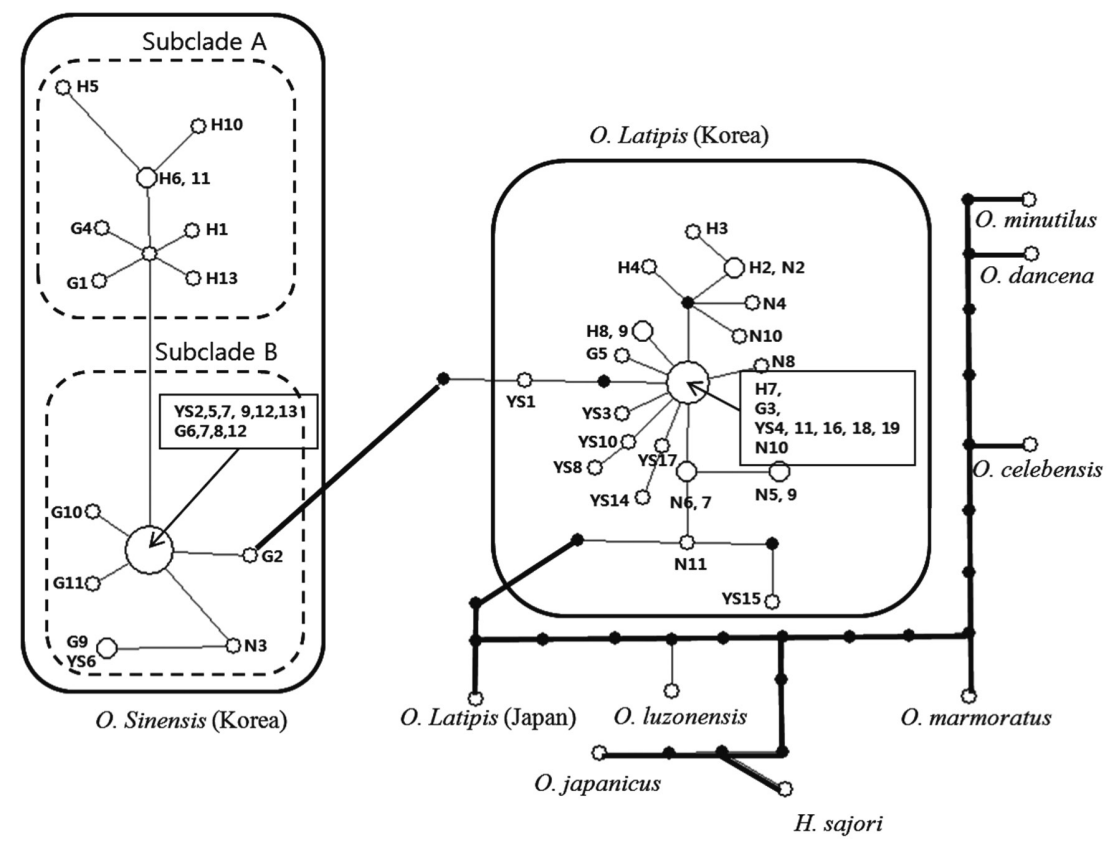

Fig. 3. Intraspecific relationship between haplotypes in Korea constructed by median-joining networks with Oryzias latipes and O. sinensis. Circles indicate each haplotype and geographical location; bold lines represent mutated regions.

identified across 25 sites; the estimated number of mutations in the shortest tree was 32 . Thus, the $O$. sinensis group is divided into two subclades by the Charyeong mountain chain; subclade A is from the Han River watershed to the northern part of the Geum River watershed and subclade B is from the southern part of the Geum River watershed to the Yeongsan and Nakdong River watershed (Fig. 3).

\section{DISCUSSION}

\section{COI region for species identification for Oryzias species}

O. latipes and O. sinensis are considered different species; they have a different number of chromosomes (Park et al. 2006) and are reproductively incompatible (Kim and Kim 1993). Recent results from mitochondrial DNA cytochrome $\mathrm{b}$ and allozyme confirmed the biogeographic and reproductive isolation of these species (Sakaizumi and Jeon 1987, Matsuda et al. 1997, Takehana et al. 2004). These results are consistent with karyotype analyses $(O$. latipes: eastern Korea grout, $2 \mathrm{n}=48$ and O. sinensis: China-western Korea group, 2n = 46) (Uwa 1986, Kim and Moon 1987, Uwa and Jeon 1987). Haplotype analysis of the mtDNA control region (Kang et al. 2005) revealed a similar distribution of $O$. sinensis.

In this study, we clearly classified two species using the mitochondrial COI region. Thus, the COI region could be used to supplement current taxonomic keys that are largely focused on morphological characteristics. In many cases, morphological classification generates identification errors due to vague criteria. Therefore, species classification using DNA markers such as the COI region (DNA barcodes) is an appropriate alternative.

$\mathrm{NJ}$ trees clearly differentiated O. latipes and O. sinensis independently. The COI sequences provided strong support for the monophyletic origin of O. latipes and $O . s i$ nensis. BP of each species was the same for 100 . Thus, the species are completely different. The K2P distance of $O$. si$n e n s i s$ was higher than that of $O$. latipes, indicating the intraspecific variation of $O$. sinensis is greater. Two clusters occurred within O. sinensis, and K2P distance was $2.17 \%$. We suspect there is more variation within $O$. sinensis. The early study conducted by Min (1997) indicated a similar result, suggesting the genetic variation of $O$. sinensis groups was about 2.5 times higher than that of $O$. latipes. Genetic variations are normally accumulated through many factors such as stability, group and habitat size, etc. (Soule 1972, 1976, Valentine 1976, Stonecking et al. 1981). Thus, we suspect differences in habitat or environmental conditions exist. 


\section{Geographic distribution of genus Oryzias}

Oryzias latipes is also distributed in China and Japan, inhabiting streams that flow into the eastern part of Korea and the islands part of southwestern Korea. In contrast, $O$. sinensis is distributed in the streams and islands of western Korea and China (Kim and Moon 1987, Kim and Lee 1992). Through allozyme studies of O. latipes in Japan, northern and southern groups were distinguished and a relationship was identified between the China and southern groups (Sakaizumi 1986). An isozyme study indicated the Korean and Japanese O. latipes groups are genetically different species (Min 1997). Such distribution could be generated by geohistorical and environmental factors. $O$. sinensis flowed into western Korea from southern China when the Korean peninsula was connected via the paleoHwangho (Yellow River) during the regression period of the Pliocene. O. latipes originated from the paleo-Amur River (Kim et al. 2005). Geographic characteristics of the Korean peninsula also support the distinct distribution of genus Oryzias. The Taebaek Mountains divide South Korea vertically into eastern and western regions, serving as a physical barrier. Stream morphology and fish species significantly differ between these regions. Thus, although similar species flowed from different sources into the Korean peninsula, they have maintained their original genetic identities because of the geographic characteristics of the Korean peninsula. In this study, O. latipes intruded into the western part of Korea. We believe this is due to anthropogenic causes, rather than natural displacement. Unintentional human releases are a significant cause for fish displacement. Also this newly found O. sinensis inhabitation sites (N3, YS 12 and YS 13). As we demonstrated, O. latipes from Japan and Korea are incorporated into different clades and the K2P distance was $16.50 \%$. Thus, the phylogeny of these groups should be reconsidered for classification. In addition, overall consideration of the genetic relationship between species in Korea, China, and Japan is required for establishing genetic divergence in Asian countries.

\section{ACKNOWLEDGEMENTS}

This work was supported by the research grant of the Kongju National University in 2012 (Project No.: 20110896).

\section{LITERATURE CITED}

Bandelt HJ, Forster P, Rohl A. 1999. Median-joining networks for inferring intraspecific phylogenies. Mol Biol Evol 16: 37-48.

Bucklin A, Hopcroft RR, Kosobokova KN, Nigro LM, Ortman BD, Jennings RM, Sweetman CJ. 2010. DNA barcoding of Arctic Ocean holozooplankton for species identification and recognition. Deep-Sea Res Pt II 57: 40-48.

Felsenstein J, Kishino H. 1993. Is there something wrong with the bootstrap on phylogeny? A reply to Hills and Bull. Syst Biol 42: 193-200.

Folmer O, Black M, Hoeh W, Lutz R, Vrijenhoek R. 1994. DNA primers for amplification of mitochondrial cytochrg ome $c$ oxidase subunit I from diverse metazoan invertebrates. Mol Mar Biol Biotech 3: 294-299.

Hebert PDN, Cywinska A, Ball SL, deWaard JR. 2003. Biological identifications through DNA barcodes. Proc R Soc Lond B Bio Sci 270: 313-322.

Hebert PDN, Gregory TR. 2005. The promise of DNA barcoding for taxonomy. Syst Biol 54: 852-859.

Hebert PDN, Penton EH, Burns JM, Janzen DH, Hallwachs W. 2004a. Ten species in one: DNA barcoding reveals cryptic species in the neotropical skipper butterfly $A s$ traptes fulgerator. Proc Natl Acad Sci USA 101: 1481214817.

Hebert PDN, Stoeckle MY, Zemlak TS, Francis CM. 2004b. Identification of birds through DNA barcodes. PLoS Biol 2: 1657-1663.

Jin SD. 2012. Phylogenetic analysis of birds in korea using mtDNA variation. PhD Dissertation. Chungnam National University, Daejeon, South Korea.

Kang TW, Lee EH, Kim MS, Paik SG, Kim S, Kim CB. 2005. Molecular phylogeny and geography of Korean medaka fish (Oryzias latipes). Mol Cells 20: 151-156.

Kim IS, Choi Y, Lee CR, Lee YJ, Kim BJ, Kim JH. 2005. The Great Illustrated Fish Book in Korea. Kyohak Publishing, Seoul. (in Korean)

Kim IS, Lee EH. 1992. New record of ricefish, Oryzias latipes sinensis (Pisces, Oryzidae) from Korea. Korean J Syst Zool 8: 177-182. (in Korean)

Kim IS, Moon KC. 1987. The karyotype of a ricefish, Oryzias latipes from southern Korea. Kor J Zool 30: 379-386. (in Korean with English abstract)

Kim IS, Kim SY. 1993. Interspecific hybridization between Oryzias sinensis and O. latipes from Korea. Kor J Ichthyol 5: 113-121. (in Korean with English abstract)

Kim IS, Park JY. 2002. Freshwater Fishes of Korea. Kyo-hak Publishing, Seoul. (in Korean)

Kimura M. 1980. A simple method for estimating evolution- 
ary rates of base substitutions through comparative studies of nucleotide sequences. J Mol Evol 16: 111-120.

Lynch M, Jarrell PE. 1993. A method for calibrating molecular clocks and its application to animal mitochondrial DNA. Genetics 135: 1197-1208.

Min MS. 1997. Genetic variation and speciation of 2 species of genus Oryzias (Pisces, Adrianichthyidae) in Korea. Korean J Syst Zool 13: 9-20. (in Korean)

Matsuda M, Yamagishi M, Sakizumi M, Jeon SR. 1997. Mitochondrial DNA variation in the Korean wild population of medaka, Oryzias latipes. Kor J Limnol 30: 119-128.

Park MK, Kim IS, Park JY. 2006. Morphological characters and geographical distributions of Korean ricefish (Pisces, Adrianichthyidae), Oryzias. Kor J Ichthyol 18: 163169.

Sakaizumi M. 1986. Genetic divergence in wild populations of medaka Oryzias latipes (Pisces: Oryziatidae) from Japan and China. Genetica 69: 119-125.

Sakaizumi M, Jeon SR. 1987. Two divergent groups in the wild populations of medaka Oryzias latipes (Pisces: Oryziatidae) in Korea. Kor J Limnol 20: 13-20.

Simmons RB, Weller SJ. 2001. Utility and evolution of cytochrome b in insects. Mol Phylogenet Evol 20: 196-210.

Smith MA, Wood DM, Janzen DH, Hallwachs W, Hebert PDN. 2007. DNA barcodes affirm that 16 species of apparently generalist tropical parasitoid flies (Diptera, Tachinidae) are not all generalists. Proc Natl Acad Sci USA 104: 4967-4972.

Smith MA, Woodley NE, Janzen DH, Hallwachs W, Hebert PDN. 2006. DNA barcodes reveal cryptic host-specificity within the presumed polyphagous members of a genus of parasitoid flies (Diptera: Tachinidae). Proc Natl Acad Sci USA 103: 3657-3662.

Soule M. 1972. The variation problem: the gene flow variation hypothesis. Taxon 20: 37-50.

Soule M. 1976. Allozyme variation: its determinants in a space and time. In: Molecular Evolution (Ayala FJ, ed).
Sinauer Associates, Sunderland, pp 60-77.

Stoneking M, Wagner DJ, Hildebrand AC. 1981. Genetic evidence suggesting subspecific differences between northern and southern populations of brook trout (Salvelinus fontinalis). Copeia 4: 810-819.

Takehana Y, Jeon SR, Sakaizumi M. 2004. Genetic structure of Korean wild populations of the medaka Oryzias latipes inferred from Allozymic variation. Zool Sci 21: 977-988.

Tamura K, Peterson N, Peterson D, Stecher G, Nei M, Kumar S. 2011. MEGA5: molecular evolutionary genetics analysis using maximum likelihood, evolutionary distance, and maximum parsimony methods. Mol Biol Evol 28: 2731-2739.

Tautz D. Arctander P, Minelli A, Thomas RH, Vogler AP. 2002. DNA points the way ahead in taxonomy. Nature 418: 479.

Tautz D, Arctander P, Minelli A, Thomas RH, Vogler AP. 2003. A plea for DNA taxonomy. Trends Ecol Evol 18: 70-74.

Uwa H. 1986. Karyotype evolution and geographical distribution in the ricefish, genus Oryzias (Oryziidae). In: Indo-Pacific Fish Biology: Proceedings of the Second International Conference on Indo-Pacific Fishes (Uyeno T, Arai T, Taniuchi T, Matsuura K, eds). Ichthyological Society of Japan, Tokyo, pp 867-876.

Uwa H, Jeon SR. 1987. Karyotypes in two divergent groups of a ricefish, Oryzias latipes, from Korea. Kor J Limnol 20: 139-147.

Valentine JW. 1976. Genetic strategies of adaptation. In: Molecular Evolution (Ayala FJ, ed). Sinauer Associates, Sunderland, MA, pp 78-94.

Ward RD, Zemlak TS, Innes BH, Last PR, Hebert PDN. 2005. DNA barcoding Australia's fish species. Philos T Roy Soc B 360: 1847-1857.

Zhang DX, Hewitt GM. 1997. Assessment of the universality and utility of a set of conserved mitochondrial COI primers in insects. Insect Mol Biol 6: 143-150. 
Appendix 1. Collection sites information of genus Oryzias (H: Han River Watershed, G: Geum River Watershed, YS: Yeongsan-Seomjin River Watershed, $\mathrm{N}$ : Nakdong River Watershed)

\begin{tabular}{|c|c|c|c|c|}
\hline \multirow{2}{*}{ Site code } & \multirow{2}{*}{ Collection site } & \multicolumn{2}{|c|}{ GPS coordination } & \multirow{2}{*}{ Collection date } \\
\hline & & latitude & longitude & \\
\hline H1 & Dongsong, Cheorwon, Gangwon & $38^{\circ} 12^{\prime} 36.00^{\prime \prime} \mathrm{N}$ & $128^{\circ} 14^{\prime} 47.03^{\prime \prime} \mathrm{E}$ & 2011.10 .03 \\
\hline $\mathrm{H} 2$ & Sonyang, Yangyang, Gangwon & $38^{\circ} 05^{\prime} 11.00^{\prime \prime} \mathrm{N}$ & $128^{\circ} 39^{\prime} 11.08^{\prime \prime} \mathrm{E}$ & 2011.10 .02 \\
\hline H3 & Gangdong, Gangneung, Gangwon & $37^{\circ} 43^{\prime} 53.02^{\prime \prime} \mathrm{N}$ & $128^{\circ} 57^{\prime} 29.05^{\prime \prime} \mathrm{E}$ & 2011.10.16 \\
\hline $\mathrm{H} 4$ & Okgye, Gangneung, Gangwon & $37^{\circ} 37^{\prime} 42.05^{\prime \prime} \mathrm{N}$ & $129^{\circ} 02^{\prime} 19.04^{\prime \prime} \mathrm{E}$ & 2011.10.16 \\
\hline H5 & Dongyang, Gyeyang, Incheon & $37^{\circ} 32^{\prime} 51.04^{\prime \prime} \mathrm{N}$ & $126^{\circ} 45^{\prime} 38.03^{\prime \prime} \mathrm{E}$ & 2011.09.18 \\
\hline H6 & Eurwang, Jung, Incheon & $37^{\circ} 26^{\prime} 44.09^{\prime \prime} \mathrm{N}$ & $126^{\circ} 23^{\prime} 37.06^{\prime \prime} \mathrm{E}$ & 2009.07.28 \\
\hline $\mathrm{H} 7$ & Muui, Jung, Incheon & $37^{\circ} 23^{\prime} 23.02^{\prime \prime} \mathrm{N}$ & $126^{\circ} 25^{\prime} 41.05^{\prime \prime} \mathrm{E}$ & 2009.07.28 \\
\hline H8 & Yeongheung, Ongjin, Incheon & $37^{\circ} 15^{\prime} 51.02^{\prime \prime} \mathrm{N}$ & $126^{\circ} 28^{\prime} 56.07^{\prime \prime} \mathrm{E}$ & 2011.09.18 \\
\hline H9 & Yeongheung, Ongjin, Incheon & $37^{\circ} 14^{\prime} 17.05^{\prime \prime} \mathrm{N}$ & $126^{\circ} 31^{\prime} 37.04^{\prime \prime} \mathrm{E}$ & 2009.05.30 \\
\hline H10 & Hajung, Siheung, Gyeonggi & $37^{\circ} 23^{\prime} 21.08^{\prime \prime} \mathrm{N}$ & $126^{\circ} 47^{\prime} 54.09^{\prime \prime} \mathrm{E}$ & 2011.09.18 \\
\hline H11 & Seongam, Danwon, Ansan, Gyeonggi & $37^{\circ} 13^{\prime} 45.06^{\prime \prime} \mathrm{N}$ & $126^{\circ} 38^{\prime} 37.06^{\prime \prime} \mathrm{E}$ & 2011.09.04 \\
\hline $\mathrm{H} 12$ & Ujeong, Hwaseong, Gyeonggi & $37^{\circ} 03^{\prime} 36.06^{\prime \prime} \mathrm{N}$ & $126^{\circ} 46^{\prime} 36.02^{\prime \prime} \mathrm{E}$ & 2011.09.13 \\
\hline H13 & Daedeok, Anseong, Gyeonggi & $37^{\circ} 02^{\prime} 09.08^{\prime \prime} \mathrm{N}$ & $127^{\circ} 12^{\prime} 51.02^{\prime \prime} \mathrm{E}$ & 2011.09.17 \\
\hline G1 & Jeongmi, Dangjin, Chungcheongnam & $36^{\circ} 52^{\prime} 47.04^{\prime \prime} \mathrm{N}$ & $126^{\circ} 36^{\prime} 06.03^{\prime \prime} \mathrm{E}$ & 2011.09.25 \\
\hline $\mathrm{G} 2$ & Chopyeong, Jincheon, Chungcheongbuk & $36^{\circ} 51^{\prime} 23.39^{\prime \prime} \mathrm{N}$ & $127^{\circ} 30^{\prime} 22.87^{\prime \prime} \mathrm{E}$ & 2011.09.15 \\
\hline G3 & Buseok, Seosan, Chungcheongnam & $36^{\circ} 45^{\prime} 34.07^{\prime \prime} \mathrm{N}$ & $126^{\circ} 23^{\prime} 08.05^{\prime \prime} \mathrm{E}$ & 2011.09.25 \\
\hline G4 & Geumma, Hongseong, Chungcheongnam & $36^{\circ} 36^{\prime} 04.06^{\prime \prime} \mathrm{N}$ & $126^{\circ} 41^{\prime} 19.00^{\prime \prime} \mathrm{E}$ & 2011.09.25 \\
\hline G5 & Naehang, Boryeong, Chungcheongnam & $36^{\circ} 20^{\prime} 34.06^{\prime \prime} \mathrm{N}$ & $126^{\circ} 35^{\prime} 04.02^{\prime \prime} \mathrm{E}$ & 2011.09.24 \\
\hline G6 & Nam, Buyeo, Chungcheongnam & $36^{\circ} 13^{\prime} 33.09^{\prime \prime} \mathrm{N}$ & $126^{\circ} 47^{\prime} 40.05^{\prime \prime} \mathrm{E}$ & 2011.09.24 \\
\hline G7 & Misan, Boryeong, Chungcheongnam & $36^{\circ} 11^{\prime} 30.07^{\prime \prime} \mathrm{N}$ & $126^{\circ} 40^{\prime} 04.07^{\prime \prime} \mathrm{E}$ & 2011.09.24 \\
\hline G8 & Hwayang, Seocheon, Chungcheongnam & $36^{\circ} 02^{\prime} 30.09^{\prime \prime} \mathrm{N}$ & $126^{\circ} 47^{\prime} 03.09^{\prime \prime} \mathrm{E}$ & 2011.09.24 \\
\hline G9 & Gaejeong, Gunsan, Jeollabuk & $35^{\circ} 57^{\prime} 46.01^{\prime \prime} \mathrm{N}$ & $126^{\circ} 46^{\prime} 290.2^{\prime \prime} \mathrm{E}$ & 2011.09.24 \\
\hline G10 & Baeksan, Gimje, Jeollabuk & $35^{\circ} 49^{\prime} 11.01^{\prime \prime} \mathrm{N}$ & $126^{\circ} 51^{\prime} 19.07^{\prime \prime} \mathrm{E}$ & 2011.11.06 \\
\hline G11 & Julpo, Buan, Jeollabuk & $35^{\circ} 36^{\prime} 39.09^{\prime \prime} \mathrm{N}$ & $126^{\circ} 42^{\prime} 49.08^{\prime \prime} \mathrm{E}$ & 2011.11.06 \\
\hline G12 & Mujang, Gochang, Jeollabuk & $35^{\circ} 23^{\prime} 16.06^{\prime \prime} \mathrm{N}$ & $126^{\circ} 35^{\prime} 32.07^{\prime \prime} \mathrm{E}$ & 2011.11.06 \\
\hline N1 & Pyeonghae, Uljin, Gyeongsangbuk & $36^{\circ} 44^{\prime} 46.09^{\prime \prime} \mathrm{N}$ & $129^{\circ} 27^{\prime} 43.01^{\prime \prime} \mathrm{E}$ & 2010.03 .18 \\
\hline $\mathrm{N} 2$ & Byeonggok, Yeongdeok, Gyeongsangbuk & $36^{\circ} 33^{\prime} 19.93^{\prime \prime} \mathrm{N}$ & $129^{\circ} 24^{\prime} 23.16^{\prime \prime} \mathrm{E}$ & 2011.05 .08 \\
\hline N3 & Dain, Uiseong, Gyeongsangbuk & $36^{\circ} 27^{\prime} 37.00^{\prime \prime} \mathrm{N}$ & $128^{\circ} 21^{\prime} 37.00^{\prime \prime} \mathrm{E}$ & 2011.11.12 \\
\hline $\mathrm{N} 4$ & Heunghae, Pohang, Gyeongsangbuk & $36^{\circ} 06^{\prime} 49.00^{\prime \prime} \mathrm{N}$ & $129^{\circ} 18^{\prime} 18.00^{\prime \prime} \mathrm{E}$ & 2009.09.11 \\
\hline N5 & Gaya, Haman, Gyeongsangnam & $35^{\circ} 17^{\prime} 20.07^{\prime \prime} \mathrm{N}$ & $128^{\circ} 23^{\prime} 59.02^{\prime \prime} \mathrm{E}$ & 2011.10 .23 \\
\hline N6 & Bongnim, Gangseo, Busan & $35^{\circ} 09^{\prime} 26.06^{\prime \prime} \mathrm{N}$ & $128^{\circ} 53^{\prime} 36.06^{\prime \prime} \mathrm{E}$ & 2011.11.13 \\
\hline N7 & Jinjeon, Changwon, Gyeongsangnam & $35^{\circ} 05^{\prime} 51.04^{\prime \prime} \mathrm{N}$ & $128^{\circ} 26^{\prime} 46.04^{\prime \prime} \mathrm{E}$ & 2011.10 .23 \\
\hline N8 & Jingyo, Hadong, Gyeongsangnam & $35^{\circ} 01^{\prime} 39.01^{\prime \prime} \mathrm{N}$ & $127^{\circ} 54^{\prime} 41.04^{\prime \prime} \mathrm{E}$ & 2011.10 .23 \\
\hline N9 & Yeoncho, Geoje, Gyeongsangnam & $34^{\circ} 54^{\prime} 11.00^{\prime \prime} \mathrm{N}$ & $128^{\circ} 38^{\prime} 45.00^{\prime \prime} \mathrm{E}$ & 2009.05.01 \\
\hline N10 & Namhae, Namhae, Gyeongsangnam & $34^{\circ} 49^{\prime} 54.62^{\prime \prime} \mathrm{N}$ & $127^{\circ} 54^{\prime} 09.02^{\prime \prime} \mathrm{E}$ & 2010.05 .01 \\
\hline N11 & Sanyang, Tongyeong, Gyeongsangnam & $34^{\circ} 48^{\prime} 24.08^{\prime \prime} \mathrm{N}$ & $128^{\circ} 23^{\prime} 09.00^{\prime \prime} \mathrm{E}$ & 2011.10 .23 \\
\hline YS1 & Gunseo, Yeonggwang, Jeollanam & $35^{\circ} 15^{\prime} 11.04^{\prime \prime} \mathrm{N}$ & $126^{\circ} 28^{\prime} 09.06^{\prime \prime} \mathrm{E}$ & 2011.11.06 \\
\hline YS2 & Hampyeong, Hampyeongn, Jeollanam & $35^{\circ} 04^{\prime} 00.00^{\prime \prime} \mathrm{N}$ & $126^{\circ} 31^{\prime} 36.03^{\prime \prime} \mathrm{E}$ & 2011.10 .08 \\
\hline YS3 & Hyeongyeong, Muan, Jeollanam & $35^{\circ} 03^{\prime} 37.01^{\prime \prime} \mathrm{N}$ & $126^{\circ} 22^{\prime} 08.02^{\prime \prime} \mathrm{E}$ & 2011.10.22 \\
\hline YS4 & Noan, Naju, Jeollanam & $35^{\circ} 03^{\prime} 39.00^{\prime \prime} \mathrm{N}$ & $126^{\circ} 44^{\prime} 31.09^{\prime \prime} \mathrm{E}$ & 2011.10 .22 \\
\hline YS5 & Mongtan, Muan, Jeollanam & $34^{\circ} 55^{\prime} 34.02^{\prime \prime} \mathrm{N}$ & $126^{\circ} 30^{\prime} 25.02^{\prime \prime} \mathrm{E}$ & 2011.10.08 \\
\hline YS6 & Dado, Naju, Jeollanam & $34^{\circ} 55^{\prime} 23.00^{\prime \prime} \mathrm{N}$ & $126^{\circ} 50^{\prime} 30.02^{\prime \prime} \mathrm{E}$ & 2009.10.11 \\
\hline YS7 & Donggang, Naju, Jeollanam & $34^{\circ} 53^{\prime} 47.04^{\prime \prime} \mathrm{N}$ & $126^{\circ} 32^{\prime} 26.06^{\prime \prime} \mathrm{E}$ & 2011.10 .08 \\
\hline YS8 & Yulchon, Yeosu, Jeollanam & $34^{\circ} 52^{\prime} 46.00^{\prime \prime} \mathrm{N}$ & $127^{\circ} 35^{\prime} 07.00^{\prime \prime} \mathrm{E}$ & 2011.11.12 \\
\hline YS9 & Illo, Muan, Jeollanam & $34^{\circ} 51^{\prime} 12.00^{\prime \prime} \mathrm{N}$ & $126^{\circ} 30^{\prime} 31.03^{\prime \prime} \mathrm{E}$ & 2011.10 .08 \\
\hline YS10 & Beolgyo, Boseong, Jeollanam & $34^{\circ} 50^{\prime} 33.08^{\prime \prime} \mathrm{N}$ & $127^{\circ} 21^{\prime} 26.04^{\prime \prime} \mathrm{E}$ & 2011.11 .12 \\
\hline YS11 & Samho, Yeongam, Jeollanam & $34^{\circ} 43^{\prime} 12.04^{\prime \prime} \mathrm{N}$ & $126^{\circ} 30^{\prime} 07.03^{\prime \prime} \mathrm{E}$ & 2011.10 .08 \\
\hline YS12 & Gangjin, Gangjin, Jeollanam & $34^{\circ} 37^{\prime} 33.00^{\prime \prime} \mathrm{N}$ & $126^{\circ} 46^{\prime} 09.04^{\prime \prime} \mathrm{E}$ & 2011.10.09 \\
\hline YS13 & Hwangsan, Haenam, Jeollanam & $34^{\circ} 34^{\prime} 05.02^{\prime \prime} \mathrm{N}$ & $126^{\circ} 24^{\prime} 04.03^{\prime \prime} \mathrm{E}$ & 2011.10.09 \\
\hline YS14 & Gunnae, Jindo, Jeollanam & $34^{\circ} 32^{\prime} 57.06^{\prime \prime} \mathrm{N}$ & $126^{\circ} 18^{\prime} 19.03^{\prime \prime} \mathrm{E}$ & 2011.10.09 \\
\hline YS15 & Sinjeon, Gangjin, Jeollanam & $34^{\circ} 31^{\prime} 19.02^{\prime \prime} \mathrm{N}$ & $126^{\circ} 43^{\prime} 36.04^{\prime \prime} \mathrm{E}$ & 2011.10.09 \\
\hline YS16 & Hoejin, Jangheung, Jeollanam & $34^{\circ} 29^{\prime} 53.09^{\prime \prime} \mathrm{N}$ & $126^{\circ} 56^{\prime} 41.00^{\prime \prime} \mathrm{E}$ & 2011.10 .22 \\
\hline YS17 & Hwasan, Haenam, Jeollanam & $34^{\circ} 29^{\prime} 19.09^{\prime \prime} \mathrm{N}$ & $126^{\circ} 30^{\prime} 24.02^{\prime \prime} \mathrm{E}$ & 2011.10 .09 \\
\hline YS18 & Gogeum, Wando, Jeollanam & $34^{\circ} 25^{\prime} 14.05^{\prime \prime} \mathrm{N}$ & $126^{\circ} 48^{\prime} 55.07^{\prime \prime} \mathrm{E}$ & 2011.10 .22 \\
\hline YS19 & Gunoe, Wando, Jeollanam & $34^{\circ} 22^{\prime} 39.08^{\prime \prime} \mathrm{N}$ & $126^{\circ} 38^{\prime} 44.09^{\prime \prime} \mathrm{E}$ & 2011.10 .09 \\
\hline
\end{tabular}

